\title{
Synthesis of A Novel Carrier Compound Thiazoethyl Methyl Eugenoxyacetate from Eugenol and Its Use in the Bulk Liquid Membrane Technique
}

\author{
Muhammad Cholid Djunaidi”, Pratama Jujur Wibawa, and Ratna Hari Murti \\ Department of Chemistry, Faculty of Science and Mathematics, Diponegoro University, \\ Jl. Prof. H. Soedarto, S.H., Tembalang, Semarang 50275, Indonesia
}

Received May 19, 2017; Accepted September 2, 2017

\begin{abstract}
Research into the synthesis and use of a novel carrier compound, thiazoethyl methyl eugenoxyacetic acid (TMEAA) for selective transport of $\mathrm{Cu}(\mathrm{II}), \mathrm{Cd}(\mathrm{II})$ and $\mathrm{Cr}$ (III) metal ions in the bulk liquid membrane (BLM) technique was conducted. TMEAA was synthesized from eugenol by acidification into eugenoxyacetic acid and subsequently esterified using 4-methyl-5-thiazoethanol. Analysis of the result was performed using GC-MS and FTIR. The TMEAA obtained was liquid, viscous, blackish-brown and fragrant, with a yield of $88 \%$. This compound was soluble in benzene and chloroform but insoluble in methanol. The GC-MS analysis showed the presence of a single peak, with a retention time of $26.5 \mathrm{~min}$, while the disappearance of vibration mode at $1727 \mathrm{~cm}^{-1}$ was attributed to acid absorption and the FTIR spectrum indicated that formation of an ester group had occurred. TMEAA was used as a carrier compound in the BLM technique to transport $\mathrm{Cu}(\mathrm{II}), \mathrm{Cd}(\mathrm{II})$ and $\mathrm{Cr}(\mathrm{III})$, using chloroform as a solvent. The results showed that TMEAA was more selective for $\mathrm{Cu}(\mathrm{II})$ and $\mathrm{Cd}(\mathrm{II})$ than $\mathrm{Cr}(\mathrm{III})$. Moreover, the research proved that $\mathrm{N}$ and $\mathrm{S}$ groups of TMEAA were selective for $\mathrm{Cu}$ (II) and $\mathrm{Cd}$ (II).
\end{abstract}

Keywords: Bulk Liquid Membrane (BLM); selective transport; thiazoethyl methyl eugenoxyacetic acid; eugenol

\section{ABSTRAK}

Telah dilakukan penelitian tentang sintesis dan penggunaan senyawa carrier tiazoetil metil eugenoksi asetat untuk transpor selektif logam-logam Cu(II), Cd(II) dan Cr(III) menggunakan Teknik Membran Cair Ruah (BLM). TMEAA disintesis dari eugenol menjadi asam eugenoksi asetat dilanjutkan dengan esterifikasi menggunakan senyawa 4-metil-5 tiazoetanol. Analisis hasil dilakukan dengan GC-MS dan FTIR. TMEAA yang diperoleh berbentuk cair, kental, berwarna coklat kehitaman, berbau harum dengan rendemen $88 \%$. Senyawa ini larut dalam benzena dan kloroform, namun sukar larut dalam metanol. Hasil analisa GC-MS menunjukkan satu puncak dengan waktu retensi 26,5 menit, sementara hilangnya serapan asam pada $1727 \mathrm{~cm}^{-1}$ pada spektra FTIR menunjukkan terbentuknya gugus ester. TMEOA hasil sintesis digunakan sebagai carrier teknik BLM dalam pelarut kloroform untuk transpor $\mathrm{Cu}(\mathrm{II}), \mathrm{Cd}(\mathrm{II})$ dan $\mathrm{Cr}(\mathrm{III})$. Hasil yang diperoleh TMEAA lebih selektif terhadap $\mathrm{Cu}(\mathrm{II})$ dan $\mathrm{Cd}(\mathrm{II})$ daripada Cr(III). Hasil penelitian membuktikan bahwa gugus N dan S dari TMEAA selektif terhadap Cu(II) dan Cd(II).

Kata Kunci: membran cair ruah; transpor selektif; tiazoetil metil eugenoksi asetat; eugenol

\section{INTRODUCTION}

Separation of heavy metals using liquid membranes is a solvent extraction method developed for use in the recovery of heavy metals from wastewater and for the extraction of valuable metals in the mining of materials. It can also be used for analysis purposes. The advantages of liquid membrane systems are that they are selective and efficient, involve low solvent consumption, are simple and inexpensive, and can be carried out continuously in a single unit operation [1]. In addition, molecular diffusion in liquids is faster than in solids, and so solid membranes with micron thicknesses cannot compete with liquid membranes in terms of transfer intensity [2].
The stability of the complex between the metal and the carrier compound determines the selectivity of separation in liquid membrane techniques. The stability of the complex is determined by several factors, including the type of donor atoms (active group) contained in the carrier compound (ligand structure), suitability for a metal electron configuration [3-7], and the $\mathrm{pH}$ of solutions [4-5]. The use of a carrier compound in liquid membrane techniques improves the efficiency and selectivity of transport [8].

Eugenol contained in clove oil has three active groups: allyl, methoxy and hydroxy. The hydroxyl group, which can be substituted by a more selective group, leads to eugenol being a potential selective carrier compound. Eugenol has been widely used for

* Corresponding author

DOI: $10.22146 /$ ijc. 25075

Email address : choliddjunaidi@live.undip.ac.id

Muhammad Cholid Djunaidi et al. 
the separation of heavy metals, including eugenol polymer (polyeugenol) used to adsorb Fe(III) ions [9-10], as a functional polymer in in-situ formations of membranes [11] and in membrane particles [12].

Eugenol derivatives with $\mathrm{N}$-donor atoms from pyridyl carbinols are selective for borderline metals $\left(\mathrm{Cu}^{2+}\right)$ [13]. The working principle of the compound carrier is based on HSAB theory (grouping acids and bases based on their hardness and softness) which states that, in general, hard metal ions (such as alkali metals, alkaline earths, and $\mathrm{Cr}^{3+}$ ) form a stronger complex with hard donor atoms (such as O) [14], soft metal ions (such as $\mathrm{Cd}^{2+}$ ) with soft donor atoms (such as S) [15] and borderline metal ions (such as $\mathrm{Cu}^{2+}$ ) with borderline donor atoms (such as $\mathrm{N}$ ) [13,16-18]. A carrier compound that has nitrogen $(N)$ and sulfur $(S)$ active groups is expected to be selective for $\mathrm{Cu}^{2+}$ and $\mathrm{Cd}^{2+}$.

In this research, $\mathrm{Cr}^{3+}, \mathrm{Cd}^{2+}$ and $\mathrm{Cu}^{2+}$ metal ions will be recovered from a waste model using thiazoethyl methyl eugenoxyacetic acid (TMEAA) synthesized from eugenol, using the BLM technique. A BLM is a simple liquid membrane used for the study of liquid membrane transport processes.

\section{EXPERIMENTAL SECTION}

\section{Materials}

The materials used in this research were eugenol p.a (SIGMA-Aldrich), BF 3 -diethylether p.a. (SIGMAAldrich), $\mathrm{SOCl}_{2}$ p.a (Merck), 4-methyl-5-thiazoleethanol p.a (Merck), NaOH p.a, (Merck), chloroacetic acid p.a (Merck), $\mathrm{CrCl}_{3} .6 \mathrm{H}_{2} \mathrm{O}$ p.a (Merck), $\mathrm{CuCl}_{2} .2 \mathrm{H}_{2} \mathrm{O}$ p.a (Merck), $\mathrm{CdCl}_{2} . \mathrm{H}_{2} \mathrm{O}$ p.a (Merck), $\mathrm{HCl}$ p.a (Merck), sodium bicarbonate p.a. (Merck), sodium sulfate anhydrate p.a. (Merck). Other reagents, including chloroform, methanol, diethyl ether and demineralized water, were purchased from Bratachem.

\section{Instrumentation}

The instruments used to characterize TMEAA in this study were FTIR Spectrophotometer (Shimadzu 8201PC), GC-MS (Shimadzu QP2010S), analytical balance (Mettler Toledo AB54-S), AAS (Perkin Elmer), $\mathrm{pH}$ meter (HACH E C20). A set of BLM tools (U-tube) was used for transport study.

\section{Procedure}

\section{Synthesis of compound carrier TMEAA}

Synthesis of eugenoxyacetic acid (EOA). Eugenol (5 g) was placed in a round-bottomed $100 \mathrm{~mL}$ boiling flask. $17.5 \mathrm{~mL} \mathrm{NaOH} \mathrm{33 \%} \mathrm{was} \mathrm{added} \mathrm{and} \mathrm{the} \mathrm{mixture} \mathrm{was}$ then stirred for approximately $30 \mathrm{~min}$. Then $12.5 \mathrm{~mL}$ of
$50 \%$ chloroacetic acid was slowly added with a pipette and the mixture was stirred constantly. The mixture was heated in a water bath with a temperature of 80 $90{ }^{\circ} \mathrm{C}$ for $2 \mathrm{~h}$, and was then cooled and acidified using $6 \mathrm{M} \mathrm{HCl}$ until the $\mathrm{pH}$ reached 1 . The next step was the extraction of the mixture three times using $50 \mathrm{~mL}$ of diethyl ether, resulting in ether extracts. The ether extracts were then combined and re-extracted three times using $30 \mathrm{~mL}$ sodium bicarbonate $5 \% \mathrm{w} / \mathrm{v}$. This extraction process produced water and ether layers. The water layer was then acidified using concentrated $\mathrm{HCl} 6 \mathrm{M}$ to achieve $\mathrm{pH} 1$. The final steps respectively were filtering, drying and weighing. The results were analyzed by FTIR.

Synthesis of TMEAA. Eugenoxyacetic acid $(3 \mathrm{~g})$ was placed in a reflux apparatus and $3 \mathrm{~mL}$ of thionyl chloride was added dropwise. The mixture was refluxed for $150 \mathrm{~min}$ in a water bath with a temperature of $40{ }^{\circ} \mathrm{C}$ and then allowed to cool at room temperature. In the next step $2.5 \mathrm{~mL}$ of thiazolethanol was adding dropwise and refluxed again in the water bath at $40{ }^{\circ} \mathrm{C}$ for $6 \mathrm{~h}$. After cooling, the result obtained was extracted using chloroform and then washed with water. The extract was dried over anhydrous sodium sulfate, filtered, and then evaporated to remove remaining solvent. The result obtained was analyzed using FTIR and GC-MS.

\section{Separation experiment}

Transport of metals using the BLM technique. TMEAA $(0.7 \mathrm{~g})$ was dissolved in $30 \mathrm{~mL}$ chloroform and was then used as a carrier compound to transport metal ions using the BLM technique. Metal ion transport using the BLM technique was carried out by filling a u-tube with a feed phase containing $13 \mathrm{~mL}$ of a mixture consisting of $30 \mathrm{ppm} \mathrm{Cu}{ }^{2+}, \mathrm{Cd}^{2+}$ and $\mathrm{Cr}^{3+}$ with $\mathrm{pH}$ of 3.2. The TMEAA carrier compound in weights $0.7,0.5$, and $0.3 \mathrm{~g}$ was then poured into $30 \mathrm{~mL}$ chloroform for each weight. In the meantime, the stripping phase contained $13 \mathrm{~mL} \mathrm{HCl}$ at a variety of

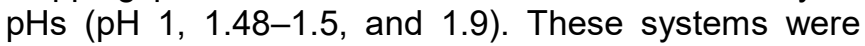
then stirred at a constant speed for $24 \mathrm{~h}$. After stirring for $24 \mathrm{~h}, \mathrm{pH}$ of both feed and receiver phases was measured using a $\mathrm{pH}$ meter. Analysis of the metal ion content in the feed and receiver phases after the separation process was carried out using an atomic absorption spectrometer.

\section{RESULT AND DISCUSSION}

This section describes the synthesis of TMEAA and its use as a carrier in the recovery of $\mathrm{Cu}^{2+}, \mathrm{Cd}^{2+}$, and $\mathrm{Cr}^{3+}$ metal ions using the BLM technique. TMEAA compound was synthesized from eugenol. Eugenol was converted into EOA, which was then converted into 


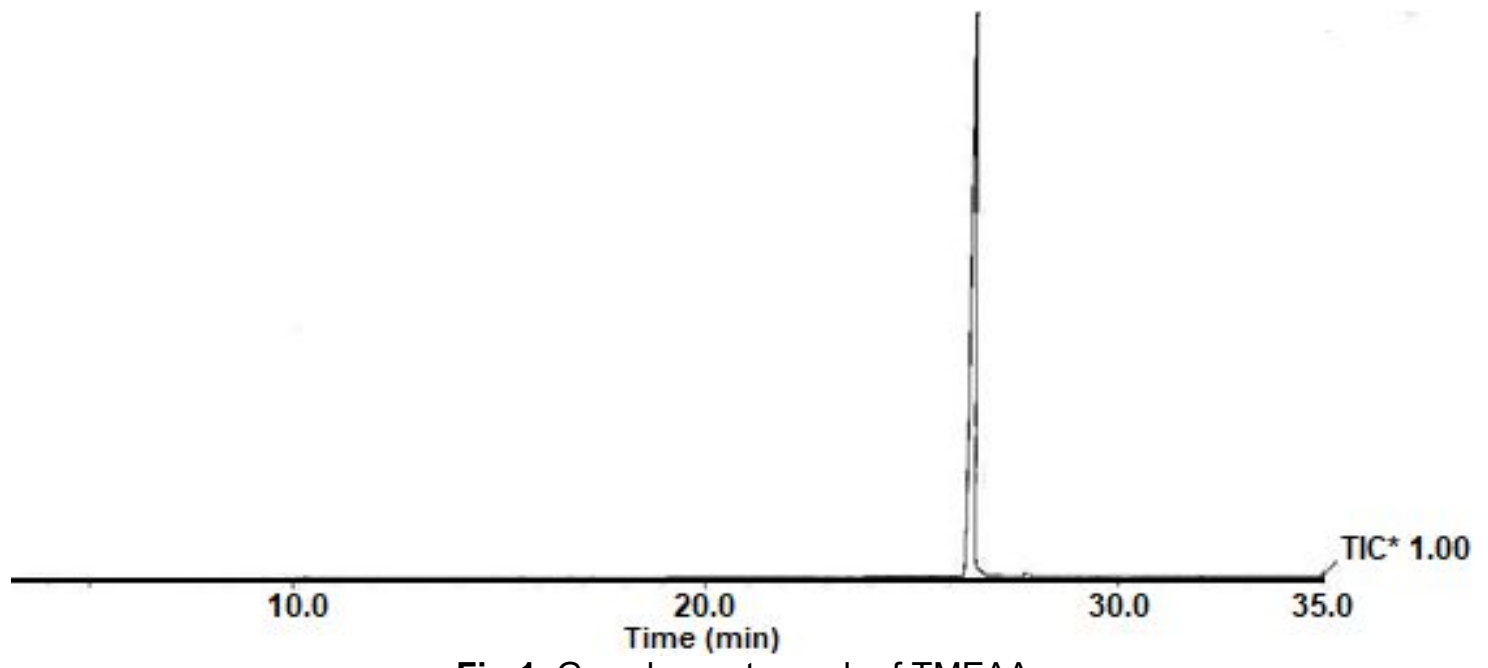

Fig 1. Gas chromatograph of TMEAA

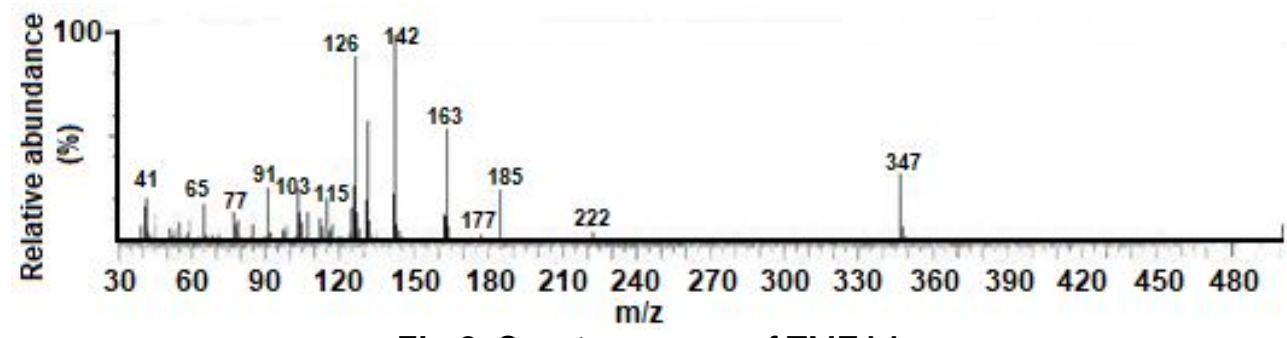

Fig 2. Spectrum mass of TMEAA

TMEAA by an esterification reaction with 4-methyl-5thiazoetanol.

\section{Synthesis of Eugenoxyacetic Acid}

The eugenoxyacetic acid synthesis was carried out by the addition of $\mathrm{NaOH}$ and chloroacetic acid. The hydroxy group in eugenol can react with $\mathrm{NaOH}$ to form a eugenolate salt. This eugenolate salt reacts easily with chloroacetic acid to form eugenoxyacetic acid.

The eugenoxyacetic acid formed was purified using diethyl ether in order to remove non-polar impurities and $\mathrm{NaHCO}_{3}$ to remove polar impurities. The eugenoxyacetic acid produced was a pure white substance, insoluble in ether, methanol, and chloroform. The yield was $77.4 \%$.

\section{Synthesis of TMEAA}

TMEAA was synthesized from the eugenoxyacetic acid by the addition of thionyl chloride. Synthesis of TMEAA is an esterification reaction which is reversible, so TMEAA should be conducted in hydrochloric acid formed by the addition of thionyl chloride so that results yield above $80 \%$ [19].

The TMEAA produced was a liquid, viscous, blackish-brown, fragrant substance, and gave a yield of $88 \%$. This compound was soluble in benzene and chloroform but insoluble in methanol. The analysis of TMEAA using GC-MS can be seen in Fig. 1, which shows a single peak with a retention time of $26.5 \mathrm{~min}$. Peak in relative abundance $(\mathrm{m} / \mathrm{z})$ of 347 and the spectrum mass of fragmentation (Fig. 2) were suitable. The FTIR spectrum of TMEAA compound is presented in Fig. 3. The absorption band in the area of $3077 \mathrm{~cm}^{-1}$ is attributed to $=\mathrm{C}-\mathrm{H} \mathrm{sp}{ }^{2}$. The absorption band at 1511 $\mathrm{cm}^{-1}$ indicates the presence of vibrations of the $\mathrm{C}=\mathrm{C}$ aromatic core, and this is supported by the absorption at $916 \mathrm{~cm}^{-1}$ region showing the aromatic substituents. The $\mathrm{sp}^{3} \mathrm{C}-\mathrm{H}$ bond absorption band appears at the 1416 $\mathrm{cm}^{-1}$ region. The vibration mode emerges at $1761 \mathrm{~cm}^{-1}$ indicating the existence of an ester carbonyl group. Based on the FTIR spectrum of the TMEAA compound, the wide band at wavenumber of 3888 and $3388 \mathrm{~cm}^{-1}$ is attributed to a hydroxyl group $(\mathrm{OH})$ which belongs to EOA [10] disappearing, proving that an ester has been formed.

Based on the analysis by GC-MS and FTIR, it can be concluded that the TMEAA was formed with high purity and molecular weight of $347 \mathrm{~g} / \mathrm{mol}$.

In the process of recovery of heavy metals using this BLM technique, changes of $\mathrm{pH}$ both in the feed and the stripping phases occurred. These $\mathrm{pH}$ changes indicated the exchange mechanism of metal and $\mathrm{H}^{+}$ ions between the two phases. The mechanism of metal 


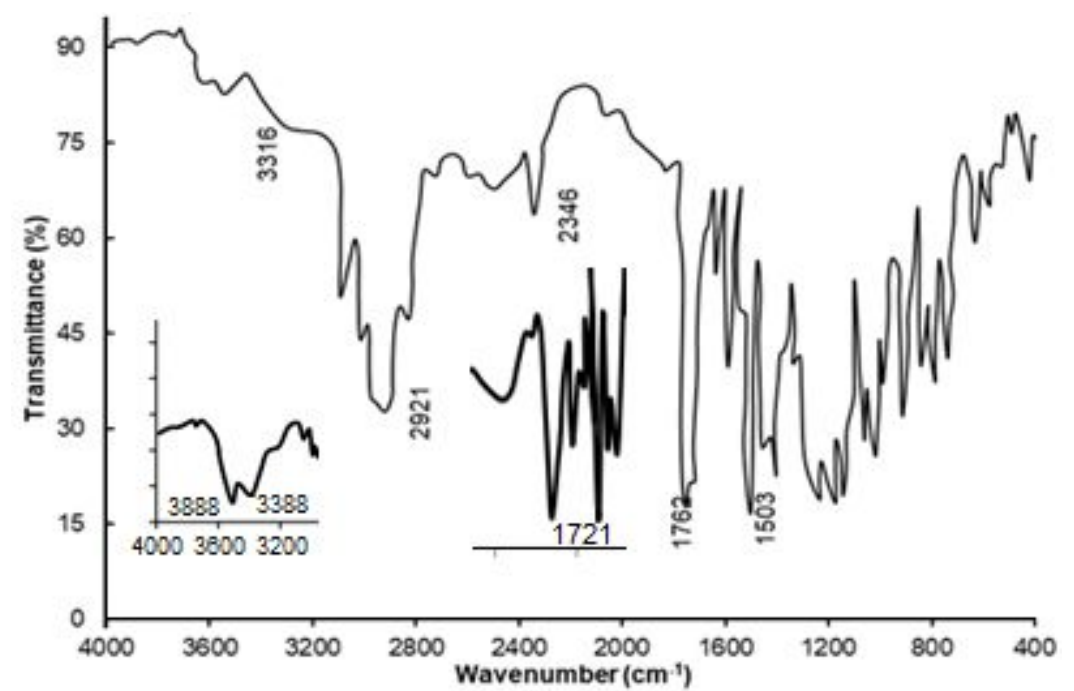

Fig 3. FTIR spectrum of TMEAA, insert FTIR spectrum of EOA

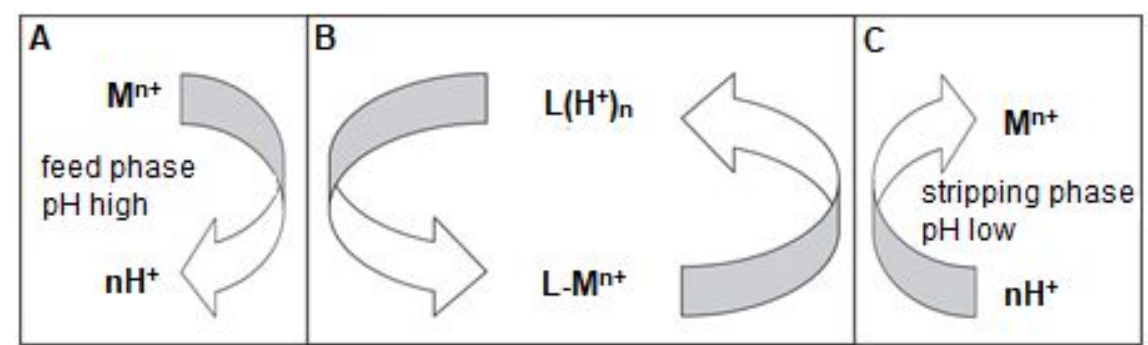

Legend: A: feed phase, B: organic phase, C: stripping phase, M: metal, L: carrier

Fig 4. Cation exchange mechanism

Table 1. Measurement of changes in $\mathrm{pH}$

\begin{tabular}{cccccc}
\hline \multirow{2}{*}{$\mathrm{pH}$} & Membrane & \multicolumn{2}{c}{$\mathrm{pH}$ feed } & \multicolumn{2}{c}{$\mathrm{pH}$ stripping } \\
\cline { 3 - 6 } & & Initial & After 24 $\mathrm{h}$ & Initial & After 24 $\mathrm{h}$ \\
\hline 1 & TMEAA-2 & 3.2 & 2.9 & 1 & 1.7 \\
& TMEAA-1 & 3.2 & 2.9 & 1.5 & 2.7 \\
1.5 & TMEAA-2 & 3.2 & 2.2 & 1.5 & 1.6 \\
& TMEAA-3 & 3.2 & 2.4 & 1.5 & 1.7 \\
1.9 & TMEAA-2 & 3.2 & 2.1 & 1.9 & 2.4 \\
\hline Legend: & & & & &
\end{tabular}

TMEAA-1: TMEAA with a mass of $0.7 \mathrm{~g}$

TMEAA-2: TMEAA with a mass of $0.5 \mathrm{~g}$

TMEAA-3: TMEAA with a mass of $0.3 \mathrm{~g}$

ion transport from the feed phase to the stripping phase through the membrane is shown in Fig. 4 and the $\mathrm{pH}$ changes are presented in Table 1.

In Table 1 the changes in $\mathrm{pH}$ after stirring for $24 \mathrm{~h}$ can be seen. In the feed phase $\mathrm{pH}$ decreased, in contrast, the $\mathrm{pH}$ increased in the stripping phase. This resulted from the feed and the membrane phase contact, in which carrier compounds bound to metal ions to form complexes and these complexes were then brought to the interface of the membrane-stripping phase. At this interface, the carrier compounds released metal ions and replaced them with $\mathrm{H}^{+}$. An $\mathrm{H}^{+}$ion in the feed phase was released and replaced with a metal ion. This process occured repeatedly until no further metal ions were exchanged.

\section{Metals Transport Using TMEAA}

Recovery of heavy metals by TMEAA in this study was conducted by performing transport with different concentration of liquid membranes to determine the selectivity and effectiveness of TMEAA used in the BLM technique. The result of metal transport at $\mathrm{pH} 1.5$ is shown in Fig. 5, which shows that the sequence of selectivity of TMEAA was $\mathrm{Cu}^{2+}, \mathrm{Cd}^{2+}$, and $\mathrm{Cr}^{3+}$, or borderline, soft, and hard metals, respectively. This 


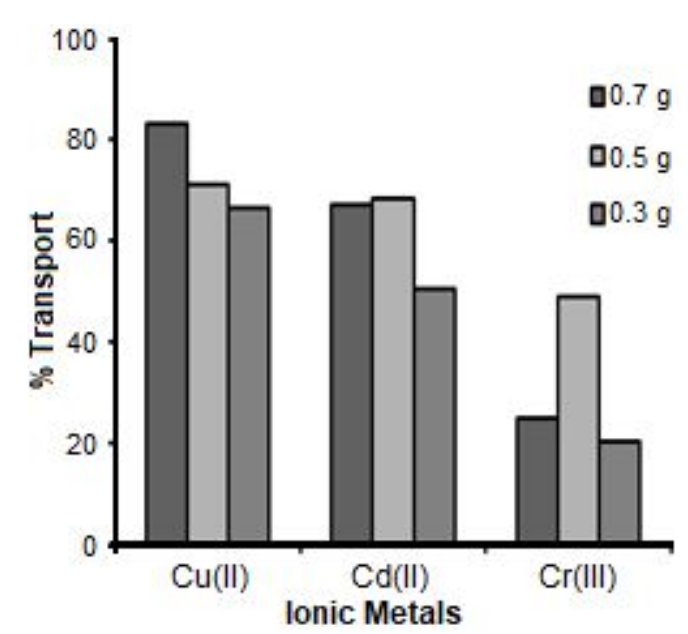

Fig 5. Heavy metal ion transport in stripping phase

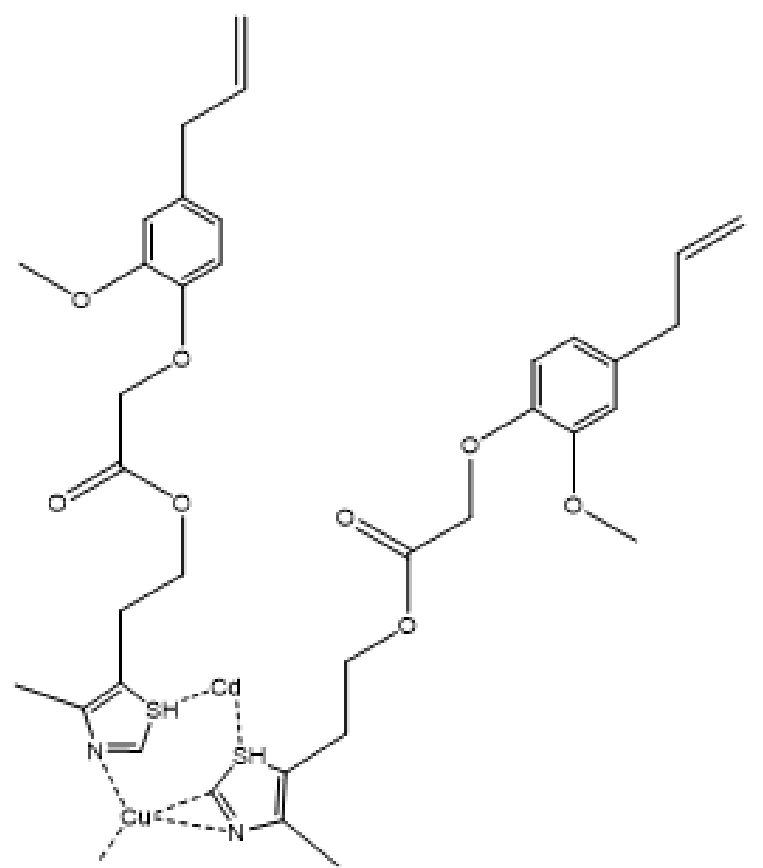

Fig 6. Interaction proposed between metal ions and TMEAA

phenomenon occurred because TMEAA contains $\mathrm{N}$ and $\mathrm{S}$ groups. $\mathrm{N}$ belongs to the borderline bases and will form strong complexes with borderline acids $\left(\mathrm{Cu}^{2+}\right)$, while the $S$ group belongs to the soft category and so will form strong complexes with soft acids $\left(\mathrm{Cd}^{2+}\right)$. This was consistent with HSAB theory [3]. Based on the transport results obtained, as shown in Fig. 6, it can be seen that the transport of $\mathrm{Cu}^{2+}$ metal ions showed the greatest percentage. This was due to the unsaturated nitrogen contained in TMEAA. The nitrogen atom bonds with a metal atom closing it in a double bond. This double bond participated in $\pi$ bonds with metal ions $\left(\mathrm{Cu}^{2+}\right)$ improving the stability of the complex [20] and so the

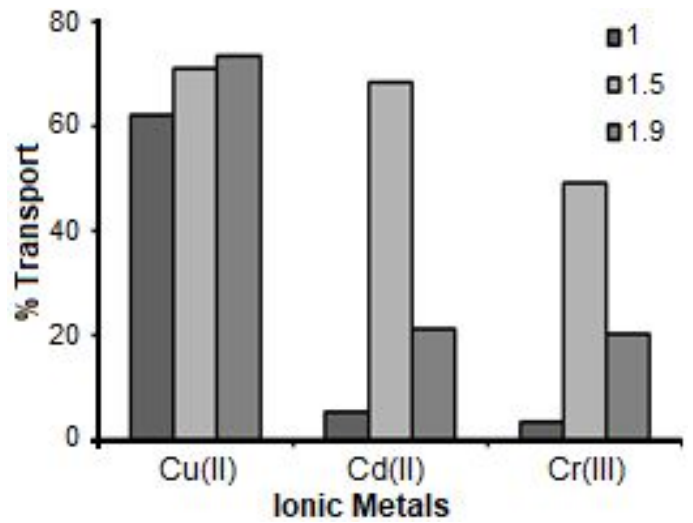

Fig 7. Ionic Metal transport at variations of $\mathrm{pH}$ in stripping phase

amount of $\mathrm{Cu}^{2+}$ transported is higher than for $\mathrm{Cd}^{2+}$ and $\mathrm{Cr}^{3+}$ (Fig. 6). The polymer of TMEAA was used by Djunaidi et al. [21] with the same objective and a similar sequence of $\mathrm{Cd}^{2+}>\mathrm{Cu}^{2+}>>\mathrm{Cr}^{3+}$ was found. Cahyono and Djunaidi [13] synthesized pyridin-2ylmethyl 2-(eugenoxy)acetate (PMEOA) as a carrier with an $\mathrm{N}$ active atom giving transport sequence $\mathrm{Cu}^{2+}>>\mathrm{Cd}^{2+}>\mathrm{Cr}^{3+}$.

The mass of the carrier compounds used can also affect the amount of metal transport [4]. The result of this research shows that the greater the mass of the carrier compound used, the more metal can be transported. The transport of heavy metals with $\mathrm{pH}$ variations is shown in Fig. 7.

Determination of the effect of $\mathrm{pH}$ in the stripping phase for metal ion transport using the BLM technique was conducted by varying the $\mathrm{pH}$ of $\mathrm{HCl}$ in the stripping phase. It can be seen in Fig. 7 that at $\mathrm{pH} 1.5, \mathrm{Cu}^{2+}$, $\mathrm{Cd}^{2+}$, and $\mathrm{Cr}^{3+}$ were transported in large enough quantities for this $\mathrm{pH}$ condition to be used for exploration. In investigating separation among the metal ions $\mathrm{pH} 1$ was used, because at $\mathrm{pH} 1, \mathrm{Cu}^{2+}$ was transported to a greater extent than $\mathrm{Cd}^{2+}$ and $\mathrm{Cr}^{3+}$. Selectivity coefficients of $\mathrm{Cu}(\mathrm{II}) / \mathrm{Cd}(\mathrm{II})$ and $\mathrm{Cu}(\mathrm{II}) / \mathrm{Cr}(\mathrm{III})$ for BLMs decreased with increasing $\mathrm{HCl}$ concentration in the stripping phase. The same tendency was reported in the literature $[6,22]$. The changes of $\mathrm{pH}$ in both feed and stripping phases can be seen in Table 1.

\section{CONCLUSION}

In the present study, TMEAA can be synthesized from eugenol and can be used as a carrier compound in the BLM technique. The $\mathrm{N}$ and $\mathrm{S}$ active groups in TMEAA act selectively with $\mathrm{Cu}^{2+}$ (borderline) and $\mathrm{Cd}^{2+}$ (soft) metal ions. 


\section{REFERENCES}

[1] Misra, B.M., and Gill, J.S., 1996, Supported liquid membranes in metal separation, ACS Symp. Ser., 642, 361-368.Ramkumar, J., and Chandramouleeswaran, S., 2015, A Perceptive on Bulk Liquid Membrane: A Brief Review, Indian J. Adv. Chem. Sci., 3 (4), 293-298.

[3] Peterson, R.T., and Lamb, J.D., 1996, Design of macrocyclic carriers for liquid membrane, ACS Symp. Ser., 642, 130-141.

[4] Nezhadali, A., and Moeinpour, F., 2013, Comparative metal ion extraction of $\mathrm{Ag}(\mathrm{I}), \mathrm{Cu}(\mathrm{II})$, $\mathrm{Ni}(\mathrm{II}), \mathrm{Zn}(\mathrm{II}), \mathrm{Mn}(\mathrm{II}), \mathrm{Cd}(\mathrm{II})$ and $\mathrm{Co}(\mathrm{II})$ cations using dibenzo $18 \mathrm{C} 6$ as a carrier, Alexandria Eng. J., 52 (1), 123-127.

[5] Kazemi, S.V., and Shamsipur, M., 2005, Selective transport of lead(II) through a bulk liquid membrane using a cooperative carrier composed of benzylaza12-crown-4 and oleic acid, Bull. Korean Chem. Soc., 26 (6), 930-934.

[6] Kazemi, S.V., and Hamidi, A.S., 2011, Competitive removal of lead(II), copper(II), and cadmium(II) ions through a bulk liquid membrane containing macrocyclic crown ethers and oleic acid as ion carriers, J. Chem. Eng. Data, 56 (2), 222-229.

[7] Eljaddi, T., Hor, M., Benjjar, A., Riri, M., Mouadli, H., Mountassir, Y., and Hlaibi, M., 2015, New supported liquid membrane for studying facilitated transport of U(VI) ions using Tributyl Phosphate (TBP) and Tri-nOctylamine (TOA) as carriers from acid medium, BAOJ Chem., 1 (1), 1-9.

[8] Bartsch, R.A., and Way, J.D., 1996, Chemical separations with liquid membranes: An overview, ACS Symp. Ser., 642, 1-10.

[9] Djunaidi, M.C., Jumina, Siswanta, D., and Ulbricht, M., 2015, Synthesis of $\mathrm{Fe}$ ionic-imprinted polyeugenol using polyethylene glycol diglycidilether as cross-linking agent for sorption of $\mathrm{Fe}(\mathrm{III})$, Indones. J. Chem., 15 (3), 305-314.

[10] Djunaidi, M.C., Jumina, and Siswanta, D., 2016, Synthesis of ionic imprinted polymer particles for selective membrane transport of $\mathrm{Fe}(\mathrm{III})$ using polyeugenol as the functional polymer, Orient. J. Chem., 32 (1), 77-84.

[11] Djunaidi, M.C., Jumina, Siswanta, D., and Ulbricht, M., 2015, Selective transport of $\mathrm{Fe}(\mathrm{III})$ using polyeugenol as functional polymer with ionic imprinted polymer membrane method, Asian $\mathrm{J}$. Chem., 27 (12), 4553-4562.
[12] Djunaidi, M.C., Jumina, Siswanta, D., and Ulbricht, M., 2016, Selective transport of $\mathrm{Fe}(\mathrm{III})$ using lonic Imprinted Polymer (IIP) membrane particle, AIP Conf. Proc., 1699 (1), 060001.

[13] Cahyono, H., and Djunaidi, M.C., 2008, Synthesis of pyridine methyl eugenoxy acetate and selectivity study of $\mathrm{Cu}(\mathrm{II})$ in Bulk Liquid Membrane (BLM) transport, Proc. Nat. Conf. Chem. Educ., Sebelas Maret University, Surakarta, Indonesia.

[14] Djunaidi, M.C., Lusiana, R.A., Wibawa, P.J., Siswanta, D., and Jumina, 2007, Sintesis polyeugenol sebagai ekstraktan selektif logam krom(III), Alchemy, 6, 40-49.

[15] Lindoy, L.F., and Baldwin, D.S., 1989, Ligand design for selective metal-ion transport through liquid membranes, Pure Appl. Chem., 61 (5), 909914.

[16] Cleij, M.C., Scrimin, P., Tecilla, P., and Tonellato, U., 1997, Efficient and highly selective copper(II) transport across a bulk liquid chloroform membrane mediated by lipophilic dipeptides, $J$. Org. Chem., 62 (16), 5592-5599.

[17] Brinchi, L., Germani, R., Mancini, M.V., Savelli, G., and Spreti, N., 2004, Carrier-mediated transport of toxic heavy metal ions in bulk liquid membranes, Eur. J. Org. Chem., 6, 1330-1335.

[18] Djunaidi, M.C., Lusiana, R.A., Wibawa, P.J., Siswanta, D., and Jumina, 2010, Sintesis turunan polieugenol sebagai carrier bagi recovery logam berat dengan teknik membran cair, Reaktor, 13 (1), 16-23.

[19] Djunaidi, M.C., Khabibi, and Trisna, D., 2010, Sintesis asam eugenoksi asetat (EOA) dari eugenol untuk ekstraktan logam berat dan recovery krom dari limbah elektroplating, Jurnal Kimia Sains dan Aplikasi, 13 (1), 12-17.

[20] Hancock, R.D., and Martell, A.E., 1989, Ligand design for selective complexation of metal ions in aqueous solution, Chem. Rev., 89 (8), 1875-1914.

[21] Djunaidi, M.C., Khabibi, and Ulumudin, I., 2017, Separation of $\mathrm{Cu}^{2+}, \mathrm{Cd}^{2+}$, and $\mathrm{Cr}^{3+}$ in a mixture solution using a novel carrier poly(methyl thiazoleethyl eugenoxy acetate) with BLM (Bulk Liquid Membrane) technique, IOP Conf. Ser. Mater. Sci. Eng., 172, 1757-1899.

[22] Ulewicz, M., Lesinska, U., Bochenska, M., and Walkowiak, W., 2007, Facilitated transport of $\mathrm{Zn}(\mathrm{II}), \mathrm{Cd}(\mathrm{II})$ and $\mathrm{Pb}(\mathrm{II})$ ions through polymer inclusion membranes with calix[4]-crown-6 derivatives, Sep. Purif. Technol., 54 (3), 299-305. 